\title{
Crowdsourcing Knowledge: An Extension Approach for Remunerative and Sustainable Home Garden Farming Systems in Kerala
}

\author{
Allan Thomas ${ }^{1}$ and M. Nithish Babu²
}

\begin{abstract}
Kerala has pioneered development models through farmer participatory approaches. Involving the grassroots in scientific studies can help improve crop variety adoption and refined technology recommendations. Participatory tools like Participatory Rural Appraisal (PRA), Participatory Technology Development (PTD), On Farm Testing (OFT), Front Line Demonstrations (FLD) and Participatory Breeding Programmes (PBP) are all time-tested examples of its successful use in researches. Crowdsourced citizen science approach called tricot - 'triadic comparisons of technologies' is popular today, where farmers are made to adopt three crop varieties or technologies randomly assigned to them from a broader set of varieties/technologies for final choice aimed at continuous adoption. The results of this study conducted during 2019-2020 revealed that more than $80 \%$ of the farmers fully adopted the technology prescribed in the checklist as a result of crowdsourcing knowledge. The results on attitude of farmers towards crowdsourcing revealed that majority of the farmers posessed favourable attitude towards crowdsourcing approach.
\end{abstract}

Keywords : Crowdsourcing; Extension Approach; Home Garden; Kerala

\section{INTRODUCTION}

Kerala is a state with miniscule sized holdings, diversified cropping patterns, predominance of perennial crops and homesteads based farming systems. Generally scientists develop high input technologies in research centres and extension experts transfer the technologies to farmers. Physical and socio-economic constraints were a major drawback for their functioning in few regions (Garforth and Harford, 1995). As quoted by Werner (1993) the main reasons for low adoption of technologies are not farmers' ignorance, but inappropriateness of many technologies, economic considerations and policy issues related to pricing and marketing. He further suggested that the development of innovations is iterative, dynamic and special process involving four stages viz., exploration of problems, identification of alternatives, their testing and assessment. John (2014) reported that the future strategies to improve homestead farming should aim at watershedbased development with focus on a wholefarm or systems approach; restructuring and refining existing home gardens, and

$\overline{{ }^{1} \text { Department of Ag. Extension, College of Agriculture, Vellayani-695 } 522{ }^{2} \text { KVK-Wayanad, Kerala Agricultural }}$ University, Kerala - 673593

Received : 05-05-2020; Accepted : 07-06-2020 
developing sustainable models through a farmer-participatory approach for each agroecological zone and forming homestead clusters.

The term "crowdsourcing" was progressively consigned to many scientific and operational initiatives aimed at collecting contributions from a large group of people. In scientific research, outstanding initiatives based on crowdsourcing accomplished to yield significant scientific outputs (Franzoni and Sauermann, 2014). Although not always denominated as crowdsourcing, there is a long tradition of participatory approaches in research and development projects in agriculture, enabling the farmers-researchers interactions or to simply collect and aggregate agricultural information from farmers (van Etten et al., 2016). Recently, Beza et al. (2017) identified crowdsourcing of farmers' data as an alternative way of getting field observations to conduct yield gap analysis, alongside with remote sensing and sensor networks. Crowdsourcing in agriculture provides inputs that meet the agricultural researchers' needs and helps closing the knowledge dissemination loop between researchers and practitioners that foster farmer-to-farmer interactions. Therefore, there are huge opportunities for scientists and practitioners in developing crowdsourcing methodologies in agriculture. In a state like Kerala, which is known for participatory approaches and grass root planning, crowdsourcing knowledge becomes important for spatial and temporal planning of homegardens. In this context, the present study was focused to know the effect of crowdsourcing knowledge on farmers and to assess the attitude of farmers towards crowd sourcing knowledge.

According to FAO (2015), Philippine Statistics Authority (PSA) with the support of FAO took up a project in Pampanga region of Philippines to assess the strength of crowdsourcing technologies to strengthen agricultural market information system. Nearly 300 rice farmers from Pampanga used simple SMS to actively sharing real-time information regarding standing crop, production area and volume and other growing conditions such as irrigation. It was found that farmers were enthusiastically participating and benefitted out of crowdsourcing. With the penetration of internet, mobile phone applications like WhatsApp are facilitating communication amongst large groups of farmers and scientists in several parts of developing countries like India and acting as efficient technology for crowdsourcing. van de Gavel et al. (2015) reported crowdsourcing as a reliable tool for research studies. A group of scientists from Sub-Saharan Africa used a crowdsourcing approach to test sorghum and cowpea varieties for climate adaptability. They asked a large group of farmers to test and evaluate different varieties and later combined farmers and morphological data of 20 varieties of cowpea and sorghum under different climatic conditions. It becomes very much evident that involving farmers in the process of decision making and enabling them to be a part of research operations, will help to synergise the research-extension system, favouring the overall output of farmers in terms of productivity and sustainable adoption. 
Crowdsourcing Knowledge: An Extension Approach for Remunerative and Sustainable Home Garden Farming Systems in Kerala

\section{METHODOLOGY}

This study was conducted in high range homegardens of Idukki district in Kerala. Based on the area and production, the study was undertaken in Adimaly panchayat of Idukki district. The crowdsourcing of knowledge was done in four stages for banana dominant homegarden systems as explained below.

A total of fifteen farmers for participating in the action research were contracted for studying the effect of crowdsourcing knowledge. These 15 farmers were selected based by consulting the Agricultural Officer of that panchayat and the willingness of the practicing farmers. To study the attitude of farmers towards crowdsourcing apart from the fifteen contracted farmers, 33 satellite farmers who received information from the fifteen contracted farmers were also selected for the study. A list of 23 attitude statements were prepared through review of literature and discussion with subject matter specialists,The twenty three statements selected were resorted to a panel of twenty five judges who were the scientists and experts in home garden farming.They were requested to mark their opinion on a five point continuum(arbitrary scale).Twenty two judges responded by sending their judgement. These responses from the 22 judges was scored and its weighted mean was determined for each

Table 1.

Final Statements Selected for Arbitrary Scale Construction

$(n=22)$

\begin{tabular}{|c|l|c|}
\hline $\begin{array}{r}\text { Sl. } \\
\text { No. }\end{array}$ & \multicolumn{1}{|c|}{ Attitude Statements } & $\begin{array}{c}\text { Weighted } \\
\text { Mean }\end{array}$ \\
\hline 1. & $\begin{array}{l}\text { Crowdsourcing is the best method that convince the farmers on production } \\
\text { potentialities per unit area }\end{array}$ & 17.6 \\
\hline 2. & Crowdsourcing is the mere waste of money, time and effort & 18.2 \\
\hline 3. & Scientist can solve the specific problem of the farming community & 19 \\
\hline 4. & Each farmers are better educated regarding the needed technology & 15.6 \\
\hline 5. & $\begin{array}{l}\text { Training programmes organized provides the practical knowledge about new } \\
\text { agricultural technologies }\end{array}$ & 19.2 \\
\hline 6. & The improved technology is feasible for the farmers & 20.6 \\
\hline 7. & Crowdsourcing provides a better teaching experience to the farmer & 21.2 \\
\hline 8. & All recommendations given in the training are profitable & 15.6 \\
\hline 9. & $\begin{array}{l}\text { Crowdsourcing helps to train field level extension functionaries and farmers } \\
\text { through its extension education activities and assisting them with scientific } \\
\text { management of crops. }\end{array}$ & 21 \\
\hline 10. & Crowdsourcing keeps you abreast of new technology & 18.8 \\
\hline \multicolumn{2}{|l|}{ Mean of weighted mean =15.57 Mandard Deviation=3.2 } \\
\hline
\end{tabular}


statements. The statement selected for the study with the weighted mean is presented in table 1. A total of 10 statements from the 23 statements that attained a higher mean score of the weighted mean (mean of weighted mean $=15.57$ and Std Dev=3.2) was selected to be administered to the actual respondents of the study. The maximum and the minimum weighted mean score for the 23 statements was 21.2 and 11.2 respectively.

\section{Focus Group Discussion-first step to crowdsourcing of knowledge}

As part of an initial investigation, Focus Group Discussion (FGD) was carried out in Machiplavu village of Idukki District in collaboration with the State Agriculture Department and local self-government bodies. A total of fifteen banana based home garden farmers as suggested by VFPCK (Vegetable and Fruit Promotion Council of Kerala) officials were purposively selected for the study. The focus group discussion was conducted for thirty minutes where the investigation team acted as facilitators and the homegarden farmers were asked to point out the major challenges in banana cultivation. They were then asked to rank the major problem confronted during the production of these crops. The investigation team listened to the presentation of problems made by the banana farmers. Possible solutions to overcome the issues of production and marketing was elicited from the farmers selected for the study and their opinions were triangulated with that of Agricultural Officer, VFPCK officials and subject experts. An appraisal of the current situation pointed out that, the major challenges faced by the banana farmers were poor yield, frequent incursion of pest and diseases and issues of marketing (Table 2). An ultimate solution to the existing problems was adoption of sustainable

Table 2.

Problems faced by Banana growers in Adimaly Panchayat of Idukki district

\begin{tabular}{|c|c|c|c|c|c|}
\hline $\begin{array}{l}\text { Priority } \\
\text { ranking }\end{array}$ & Problem & $\begin{array}{l}\text { Priority } \\
\text { ranking }\end{array}$ & Problem & $\begin{array}{l}\text { Priority } \\
\text { ranking }\end{array}$ & Problem \\
\hline I & $\begin{array}{l}\text { Severity of pest and } \\
\text { disease }\end{array}$ & V & Water logging & IX & $\begin{array}{l}\text { No facilities for } \\
\text { testing soil nutrient } \\
\text { status timely }\end{array}$ \\
\hline II & $\begin{array}{l}\text { Unaware of new } \\
\text { technologies and } \\
\text { practices }\end{array}$ & VI & $\begin{array}{l}\text { Inappropriate } \\
\text { fertilizer } \\
\text { management }\end{array}$ & $x$ & $\begin{array}{l}\text { High commission of } \\
\text { intermediaries }\end{array}$ \\
\hline III & $\begin{array}{l}\text { Non-availability of } \\
\text { proper market }\end{array}$ & VII & $\begin{array}{l}\text { High incidence of } \\
\text { weeds }\end{array}$ & $X I$ & Price-fluctuation \\
\hline IV & $\begin{array}{l}\text { Heavy damage by } \\
\text { wind }\end{array}$ & VIII & High cost of inputs & XII & $\begin{array}{l}\text { Lack of storage } \\
\text { facilities }\end{array}$ \\
\hline
\end{tabular}


Crowdsourcing Knowledge: An Extension Approach for Remunerative and Sustainable Home

Garden Farming Systems in Kerala

scientific farming practices by individual farmers that leads to the potential yield in banana and centralised collective marketing of the produce in the production catchments itself, thereby ensuring remunerative price for the produce. So in order to demonstrate the importance of scientific technologies, an action research was undertaken, as per the technology recommendations put forward by the Kerala Agricultural University - Package of Practices.

Contracting the farmers for crowdsourcing and action

A total of fifteen banana farmers participated in the focus group discussion. Three banana farmers who were ready to fully cooperate with the investigation team were contracted through consensus to adopt the KAU Package of Practices recommendations. The investigation team gave all the inputs starting from land preparation to harvesting for the contracted farmers. The remaining twelve farmers were asked to follow the packages adopted by the contracted farmers. One lead farmer was selected among the fifteen farmers through sociometric techniques and the role of the lead farmers was to monitor the activities of all other participating farmers.

Farmer-expert participatory preparation of the checklist as a part of crowdsourcing

A checklist was prepared for carrying out the cultivation practices in timely and proper manner with the help of experts in each field considering the opinion of the participating farmers. The checklists were given to all the fifteen farmers and they were educated to record the activities that have been done in their respective home gardens which were monitored by the lead farmer in the group.

Training for participatory action and learning of high range home garden farmers

A training programme was conducted for the fifteen farmers on different production technologies of banana. Further they were asked to disseminate the technology to the neighbouring farmers who were interested in banana cultivation. During the training period, discussions were conducted by the research team with the farmers on different varieties suited for the ecological unit. They were briefed upon the merits and de merits, after which farmers were given a freehand to select the variety of their choice from a basketful of opportunities. Followed by it, selected lead farmer's were trained on scientific management of banana from temporal and spatial choice to harvesting and marketing of produce. A check list was created through farmer consultative approach and they were sensitised to document their day to day activities, which was the most important aspect of crowdsourcing knowledge. The record keeping was monitored by the lead farmers with regular advisory support from the research team through extension support using social networks.

\section{FINDINGS AND DISCUSSION}

The activity cum checklist adopted by the participating farmers under the concurrent evaluation of lead farmers is presented in Table 3. 
It is evident from Table 3 that more than eighty per cent of the farmers fully adopted the technology prescribed in the checklist, and the partial adoption was due to the climate aberration that has occurred, but they have followed the practices either one week after or prior to the suggested dates. In this study partial adoption was operationalised as the number of farmers who have not adopted the package of practice technologies on the recommended dates suggested by the investigation team. The noticeable fact was that during an outbreak of pest and disease, the farmers immediately reported to the lead farmer and the lead farmer mobilized a meeting in his field and renedered suggestions to participating farmers. These meetings were informed to the investigation team as well who acted as virtual advisors. Proper management practices were suggested and almost 80 per cent of the farmers followed the practices that were suggested by the team. Eventhough the

Table 3.

Checklist monitored by the Lead Farmer through Crowd Sourcing and Percentage Adoption of Activities by Participating Farmers

$(n=15)$

\begin{tabular}{|c|c|c|c|c|c|c|c|c|}
\hline \multirow[t]{2}{*}{$\begin{array}{l}\text { Sl. } \\
\text { No. }\end{array}$} & \multirow[t]{2}{*}{ Date } & \multirow[t]{2}{*}{$\begin{array}{c}\text { Cultivation Practices/ } \\
\text { Activities }\end{array}$} & \multicolumn{2}{|c|}{$\begin{array}{l}\text { No. of } \\
\text { Farmers } \\
\text { Fully Adopted }\end{array}$} & \multicolumn{2}{|c|}{$\begin{array}{l}\text { No. of Farmers } \\
\text { Partially } \\
\text { Adopted }\end{array}$} & \multicolumn{2}{|c|}{$\begin{array}{l}\text { No. of } \\
\text { Farmers } \\
\text { Not } \\
\text { Adopted }\end{array}$} \\
\hline & & & No & $\%$ & No & $\%$ & No & $\%$ \\
\hline 1. & $15-09-2018$ & $\begin{array}{l}\text { Paring and pralinage (rhizomes } \\
\text { are smeared with cowdung } \\
\text { solution and dried under sunlight } \\
\text { for about } 4 \text { days followed by } \\
\text { shade drying up to } 15 \text { days) }\end{array}$ & 12 & 80 & 2 & 13.33 & 1 & 6.67 \\
\hline 2. & 30-09-2018 & $\begin{array}{l}\text { Land preparation and taking pits } \\
\text { of size } 50 * 50 * 50\end{array}$ & 13 & 86.66 & 1 & 6.67 & 1 & 6.67 \\
\hline 3. & 30-09-2018 & $\begin{array}{l}\text { Planting of suckers at a spacing of } \\
2 m^{*} 2 m\end{array}$ & 15 & 100 & 0 & 0 & 0 & 0 \\
\hline 4. & $30-09-2018$ & $\begin{array}{l}\text { Application of organic manure @ } \\
10 \mathrm{~kg} / \text { plant }\end{array}$ & 11 & 73.34 & 2 & 13.33 & 2 & 13.33 \\
\hline 5. & 30-09-2018 & $\begin{array}{l}\text { Sowing of cowpea/daincha/sun } \\
\text { hemp @ a seed rate of } 50 \text { kg ha- }{ }^{-1}\end{array}$ & 14 & 93.33 & 0 & 0 & 1 & 6.67 \\
\hline 6. & 1-11-2018 & $\begin{array}{l}\text { Application of first split dose of } \\
\text { fertilizers, } \mathrm{N}: \mathrm{P}_{2} \mathrm{O}_{5}: \mathrm{K}_{2} \mathrm{O}, 40: 65: 60 \\
\text { g/plant/year }\end{array}$ & 13 & 86.66 & 0 & 0 & 2 & 13.33 \\
\hline
\end{tabular}


Crowdsourcing Knowledge: An Extension Approach for Remunerative and Sustainable Home Garden Farming Systems in Kerala

\begin{tabular}{|c|c|c|c|c|c|c|c|c|}
\hline \multirow[t]{2}{*}{$\begin{array}{l}\text { Sl. } \\
\text { No. }\end{array}$} & \multirow[t]{2}{*}{ Date } & \multirow[t]{2}{*}{$\begin{array}{c}\text { Cultivation Practices/ } \\
\text { Activities }\end{array}$} & \multicolumn{2}{|c|}{$\begin{array}{c}\text { No. of } \\
\text { Farmers } \\
\text { Fully Adopted }\end{array}$} & \multicolumn{2}{|c|}{$\begin{array}{l}\text { No. of Farmers } \\
\text { Partially } \\
\text { Adopted }\end{array}$} & \multicolumn{2}{|c|}{$\begin{array}{l}\text { No. of } \\
\text { Farmers } \\
\text { Not } \\
\text { Adopted }\end{array}$} \\
\hline & & & No & $\%$ & No & $\%$ & No & $\%$ \\
\hline 7. & 8-11-2018 & $\begin{array}{l}\text { Incorporation of cowpea/daincha } \\
\text { /sun hemp in to the soil }\end{array}$ & 14 & 93.33 & 0 & 0 & 1 & 6.67 \\
\hline 8. & $2-11-2018$ & $\begin{array}{l}\text { Application of second split } \\
\text { dose of fertilizers } \mathrm{N}: \mathrm{P}_{2} \mathrm{O}_{5}: \mathrm{K}_{2} \mathrm{O} \text {, } \\
\text { 30:50:60 g/plant/year }\end{array}$ & 12 & 80 & 1 & 6.67 & 2 & 13.33 \\
\hline 9. & 8-12-2018 & Desuckering & 14 & 93.33 & 1 & 6.67 & 0 & 0 \\
\hline 10. & 1-1-2019 & $\begin{array}{l}\text { Application of third split dose of } \\
\text { fertilizers } \mathrm{N}: \mathrm{P}_{2} \mathrm{O}_{5}: \mathrm{K}_{2} \mathrm{O}, 30: 00: 60 \\
\text { g/plant/year }\end{array}$ & 15 & 100 & 0 & 0 & 0 & 0 \\
\hline 11. & 5-1-2019 & $\begin{array}{l}\text { Record of biometric observations } \\
\text { viz., plant height, girth of } \\
\text { pseudostem, number of leaves, } \\
\text { leaf area index etc. }\end{array}$ & 12 & 80 & 3 & 20 & 0 & 0 \\
\hline 12. & $1-2-2019$ & $\begin{array}{l}\text { Application of fourth split dose of } \\
\text { fertilizers } \mathrm{N}: \mathrm{P}_{2} \mathrm{O}_{5}: \mathrm{K}_{2} \mathrm{O}, 30: 00: 60 \\
\text { g/plant/year }\end{array}$ & 11 & 73.34 & 2 & 13.33 & 2 & 13.33 \\
\hline 13. & $\begin{array}{l}\text { Contingent } \\
\text { monitoring } \\
\text { and } \\
\text { reporting } \\
\text { during the } \\
\text { emergence } \\
\text { of pest \& } \\
\text { disease }\end{array}$ & $\begin{array}{l}\text { Monitoring of pest and disease } \\
\text { incidence and timely application } \\
\text { of management practices }\end{array}$ & 12 & 80 & 3 & 20 & 0 & 0 \\
\hline 14. & 1-3-2019 & $\begin{array}{l}\text { Application of fifth split dose of } \\
\text { fertilizers } \mathrm{N}: \mathrm{P}_{2} \mathrm{O}_{5}: \mathrm{K}_{2} \mathrm{O}, 30: 00: 60 \\
\text { g/plant/year }\end{array}$ & 13 & 86.66 & 1 & 6.67 & 1 & 6.67 \\
\hline 15. & $1-4-2019$ & $\begin{array}{l}\text { Application of final split dose of } \\
\text { fertilizers just after the complete } \\
\text { emergence of bunch. ( } \mathrm{N}: \mathrm{P}_{2} \mathrm{O}_{5} \text { : } \\
\mathrm{K}_{2} \mathrm{O}, 30: 00: 00 \mathrm{~g} / \text { plant/year) }\end{array}$ & 11 & 73.34 & 2 & 13.33 & 2 & 13.33 \\
\hline
\end{tabular}




\begin{tabular}{|c|c|c|c|c|c|c|c|c|}
\hline \multirow[t]{2}{*}{$\begin{array}{l}\text { Sl. } \\
\text { No. }\end{array}$} & \multirow[t]{2}{*}{ Date } & \multirow[t]{2}{*}{$\begin{array}{c}\text { Cultivation Practices/ } \\
\text { Activities }\end{array}$} & \multicolumn{2}{|c|}{$\begin{array}{c}\text { No. of } \\
\text { Farmers } \\
\text { Fully Adopted }\end{array}$} & \multicolumn{2}{|c|}{$\begin{array}{l}\text { No. of Farmers } \\
\text { Partially } \\
\text { Adopted }\end{array}$} & \multicolumn{2}{|c|}{$\begin{array}{l}\text { No. of } \\
\text { Farmers } \\
\text { Not } \\
\text { Adopted }\end{array}$} \\
\hline & & & No & $\%$ & No & $\%$ & No & $\%$ \\
\hline 16. & $14-4-2019$ & $\begin{array}{l}\text { Pre harvest bunch spray of } 3 \text { per } \\
\text { cent } \mathrm{K}_{2} \mathrm{SO}_{4} \text { at two weeks after } \\
\text { bunch emergence }\end{array}$ & 13 & 86.66 & 1 & 6.67 & 1 & 6.67 \\
\hline 17. & 28-4-2019 & $\begin{array}{l}\text { Pre harvest bunch spray of } 3 \text { per } \\
\text { cent } \mathrm{K}_{2} \mathrm{SO}_{4} \text { at four weeks after } \\
\text { bunch emergence }\end{array}$ & 13 & 86.66 & 1 & 6.67 & 1 & 6.67 \\
\hline 18. & $\begin{array}{l}\text { As on } 3 \text { July } \\
2019 \\
\end{array}$ & $\begin{array}{l}\text { Observations on yield and yield } \\
\text { attributes }\end{array}$ & 15 & 100.0 & 0 & 0 & 0 & 0 \\
\hline & & Mean adoption (\%) & & 86.3 & & 7.4 & & 6.3 \\
\hline
\end{tabular}

mean adoption percentage was 86.3 for full adoption of practices it was interesting to note that three out of 18 activities, viz., planting of suckers at a spacing of $2 m^{*} 2 m$, application of third split dose of fertilizers $\mathrm{N}: \mathrm{P}_{2} \mathrm{O}_{5}: \mathrm{K}_{2} \mathrm{O}$, 30:00:60 $\mathrm{g} / \mathrm{plant} /$ year and observations on yield and yield attributes were adopted by 100 per cent farmers. It indicates the mind set of farmers on the importance they attach to important phase of crop growth for deriving maximum yield and profit. This again can be reiterated from the fact that when all the farmers (100\%) adopted the third split application of NPK fertilizers (during flower bud differentiation stage), the percentage adoption for the first, second, fourth, fifth and sixth final split was $86.66 \%, 80 \%$, $73.34 \%, 86.66 \%$ and $73.34 \%$ respectively. Through crowdsourcing knowledge, farmers understood the importance of applying pre harvest bunch spray of 3 per cent $\mathrm{K}_{2} \mathrm{SO}_{4}$ at second and fourth weeks after bunch emergence, wherein, 86.66 percent of farmers adopted the same. The high adoption of almost all practices or activities can be attributed resultant to the outcome of crowdsourcing knowledge through farmer participatory approaches transforming them from citizen farmer to farmer scientist with enhanced knowledge, responsibility and pride.

The perception of banana farmers on the benefits of crowdsourcing knowledge was worked out in terms of perception index based on the responses of participating farmers and the results are presented in Table 4.

Perception scale consisted of ten statements measured in a five-point continuum viz., strongly agree, agree, undecided, disagree and strongly disagree. Table 3 depicts that majority of the farmers strongly agreed with the perception statements such as crowd sourcing have enabled them to-mobilize communities for meeting (100\%), adopt new technologies 
Crowdsourcing Knowledge: An Extension Approach for Remunerative and Sustainable Home

Garden Farming Systems in Kerala

Table 4.

Perception Index of Farmers on Crowdsourcing in Disseminating the Knowledge

$(n=15)$

\begin{tabular}{|c|l|l|}
\hline $\begin{array}{r}\text { Sl. } \\
\text { No }\end{array}$ & \multicolumn{1}{|c|}{ Statements } & $\begin{array}{c}\text { Farmer } \\
\text { Response }\end{array}$ \\
\hline 1. & I have gained confidence in communicating with fellow farmers & 93.33 \\
\hline 2. & I am able to provide technical advice to the farmers & 80.00 \\
\hline 3. & Crowd sourcing of knowledge is better than conventional method & 100.0 \\
\hline 4. & It has improved my social status & 80.00 \\
\hline 5. & I am able to monitor or supervise activities that are given by the scientists & 73.33 \\
\hline 6. & Identify problems and call for assistance & 93.33 \\
\hline 7. & It helps in mobilizing communities for meetings & 100.0 \\
\hline 8. & Greater economic prosperity can be achieved through crowdsourcing & 93.33 \\
\hline 9. & Crowdsourcing helps farmers to adopt new technologies and methods & 100.0 \\
\hline 10. & My social networks have increased & 86.66 \\
\hline
\end{tabular}

and methods (100\%), identify problems and call for assistance (93.33\%) and gain confidence to communicate with the fellow farmers (93.33\%). The High response percentage $(93.33 \%)$ for the statement 'greater economic prosperity can be achieved through crowdsourcing' could be because the experiment resulted on remunerative yield to the farmers (B:C $=2.77$ as against the previous average 1.63). Homegarden banana farmers' perception that crowd sourcing of knowledge is better than conventional method of participation (100\%) reflects the attitude of farmers towards new initiatives that can auger meaningful involvement for better decision making, which in turn will keep farmers motivated for continuous improvement through improved adoption of scientific practices. This also reflected on the attitude of farmers towards crowdsourcing knowledge which was worked out for which the results are presented in Tables 5 and 6.
Table 5 shows the attitude of the farmers towards crowdsourcing knowledge on technology for banana cultivation. Majority of the farmers (60.42\%) agreed that the 'Crowdsourcing is the best method that convince the farmers on production potentialities per unit area'. In the meantime 50.00 percent of the farmers strongly disagreed to the statement that the crowdsourcing is a mere waste of money, time and effort, even though $(16.67 \%)$ of the farmers agreed with the statement. More than half ( $52.08 \%$ each) of the farmers strongly agreed for the statements 'each farmers are better educated regarding the needed technology'; 'training programmes organized provides the practical knowledge about new agricultural technologies' and 'the improved technology is feasible for the farmers', Majority of the farmers (68.75\%) strongly agreed that crowdsourcing provides a better teaching-learning experience to the 
Table 5.

Attitude of Farmers towards Crowdsourcing Knowledge

$(n=48)$

\begin{tabular}{|c|c|c|c|c|c|c|}
\hline $\begin{array}{l}\text { SI. } \\
\text { No. }\end{array}$ & Attitude Statements & $\begin{array}{c}\text { SA } \\
\%\end{array}$ & $\begin{array}{l}\text { A } \\
\%\end{array}$ & $\begin{array}{c}\text { UD } \\
\%\end{array}$ & $\begin{array}{l}\text { DA } \\
\%\end{array}$ & $\begin{array}{c}\text { SDA } \\
\%\end{array}$ \\
\hline 1. & $\begin{array}{l}\text { Crowdsourcing is the best method that convince } \\
\text { the farmers on production potentialities per unit } \\
\text { area }\end{array}$ & 60.42 & 33.33 & 4.17 & 2.08 & 0 \\
\hline 2. & $\begin{array}{l}\text { Crowdsourcing is the mere waste of money, time } \\
\text { and effort }\end{array}$ & 4.17 & 16.67 & 18.75 & 10.42 & 50.0 \\
\hline 3. & $\begin{array}{l}\text { Scientist can solve the specific problem of the } \\
\text { farming community }\end{array}$ & 41.67 & 41.67 & 12.50 & 4.17 & 0 \\
\hline 4. & $\begin{array}{l}\text { Each farmers are better educated regarding the } \\
\text { needed technology }\end{array}$ & 52.08 & 25.00 & 18.75 & 4.17 & 0 \\
\hline 5. & $\begin{array}{l}\text { Training programmes organized provides the } \\
\text { practical knowledge about new agricultural } \\
\text { technologies }\end{array}$ & 52.08 & 25.00 & 8.33 & 14.58 & 0 \\
\hline 6. & $\begin{array}{l}\text { The improved technology is feasible for the } \\
\text { farmers }\end{array}$ & 52.08 & 29.17 & 16.67 & 2.08 & 0 \\
\hline 7. & $\begin{array}{l}\text { Crowdsourcing provides a better teaching-learning } \\
\text { experience to the farmer }\end{array}$ & 68.75 & 14.58 & 10.42 & 6.25 & 0 \\
\hline 8. & $\begin{array}{l}\text { All recommendations given in the training are } \\
\text { profitable }\end{array}$ & 58.33 & 25.00 & 6.25 & 10.42 & 0 \\
\hline 9 & $\begin{array}{l}\text { Crowdsourcing helps to train field level extension } \\
\text { functionaries and farmers through its extension } \\
\text { education activities and assisting them with } \\
\text { scientific management of crops. }\end{array}$ & 52.08 & 22.92 & 18.75 & 6.25 & 0 \\
\hline 10. & $\begin{array}{l}\text { Crowdsourcing keeps you abreast of new } \\
\text { technology }\end{array}$ & 54.17 & 22.92 & 8.33 & 12.50 & 2.08 \\
\hline
\end{tabular}

(SA: Strongly Agree; A: Agree; UD: Undecided; DA: Disagree; SDA: Strongly disagree)

farmer. Most of the farmers (58.33\%) were of the opinion that all the recommendation given in the training are profitable. More than half of the farmers (54.17\%) agreed that the crowdsourcing keeps farmers abreast of new technology.
Table 5 revealed the attitude of farmers towards crowdsourcing. In order to measure the attitude of farmers towards crowdsourcing, a total of forty seven farmer respondents were taken which included fifteen trained farmers and thirty two farmers 
Crowdsourcing Knowledge: An Extension Approach for Remunerative and Sustainable Home

Garden Farming Systems in Kerala

Table 6.

Distribution of Farmers based on Their Attitude towards Crowdsourcing

$(n=48)$

\begin{tabular}{|c|c|c|c|c|}
\hline Sl. No. & Degree of Attitude & Criterion & Frequency & Percentage \\
\hline 1 & Most favourable & Mean + SD & 13 & 27.08 \\
\hline 2 & Favourable & Mean \pm SD & 26 & 54.16 \\
\hline 3 & Least favourable & Mean - SD & 09 & 18.75 \\
\hline \multicolumn{2}{|c|}{ Total } & \multicolumn{2}{|c|}{48} \\
\cline { 4 - 4 } & Mean & \multicolumn{2}{|c|}{42.5} \\
& SD & \multicolumn{2}{|c|}{7.40} \\
\hline
\end{tabular}

for whom the technology was disseminated by the trained farmers. The result revealed that more than fifty per cent $(54.16 \%)$ and nearly thirty percent $(27.08 \%)$ of the farmers have favourable and most favourable attitude respectively towards crowdsourcing approach. The maximum and minimum scores obtained for the individual farmer were 50 and 22 respectively. This unequivocally establishes the fact that crowdsourcing of knowledge with more responsibilities and accountability attached to farmers can favourably influence the attitude of farmers. It will help in accelerating the process of technology transfer and augmenting continuous better adoption facilitating a positive effect in the socio-biophysical and economic realm of the practicing farmers.

\section{CONCLUSION}

Crowdsourcing is a budding approach that has a capacity to overcome the problem faced by farmers at grass root level. It augment farmers for transforming themselves to farmer scientists with improved scientific knowledge, accountability, responsibility and pride.Crowdsourcing knowledge of farmers can be a potential extension tool as the homegarden farming system in Kerala facilitates horizontal integration of different crops that is more dependent on family labour than hired agricultural labour. Crowdsourcing helps to disseminate the knowledge across a wider areas as farmers receive consistent information on different production practices, hence overcoming information lag that exist in the way of production processes, this approach also allows the farmers to make systematic evaluation and compare the effectiveness of the technology with the results of other farmers.

\section{REFERENCES}

Beza, E. Silva, J.V. Kooistra, L. \& Reidsma, P. (2017), Review of yield gap explaining factors and opportunities for alternative data collection approaches, European Journal of Agronomy 82B, 206-222.

FAO [Food and agricultural organisation]. (2015). Agriculture sector to take advantage of crowdsourcing technologies. [online]. 
Retrieved from http://fao.org/phill/news/ detail/en/c/887552/.

Franzoni, C. \& Sauermann, H. (2014), Crowd science: The organization of scientific research in open collaborative projects, Research Policy 43(1), 1-20.

Garforth, C. \& Harford, N. (1995). Issues in Agricultural ExtensionExperiences of Agriculture and Natural Resource Management Programmes through the 1980s and 1990s, AERDD Working Paper 95/6,The University of Reading,UK.

John, J. (2014). Homestead farming in Kerala: A multi-faceted land use system. Review of agrarian studies, 4 (1): 80 94

van Etten, J, Beza, E, Calderer, L, van Duijvendijk, K, Fadda, C, Fantahun, B,
Kidane, Y. G, van de Gevel, J, Gupta, A, Mengistu, D. K, Kiambi, D, Mathur, P. N, Mercado, L, Mittra, S, Mollel, M. J, Rosas, J. C, Steinke, J, Suchini, J. G, \& Zimmerer, K.S. (2016). First experiences with a novel farmer citizen science approach: crowdsourcing participatory variety selection through onfarm triadic comparisons of technologies, Experimental Agriculture, 1-22.

van de Gevel, J.M.J., Kiambi, D., \& Fadda, C. (2015). Using a crowdsourcing approach to test sorghum and cowpea varieties for climate adaptability. Procedia Environ. Sci 29(1) $243-244$

Werner, J. (1993). Participatory Development of Innovations: Procedures and Methods of On Farm Research. GTZ Swiss Development Cooperation, Federal Republic of Germany, $225 p$. 